\title{
Fire ton våben over Indien
}

\section{Vibeke Sperling}

\section{Sagen om en danskers nedkastning af våben til oprørere i Vestbengalen kaster lange og dyre skygger over de indisk-danske relationer}

Sidst i september skete nyt i den fastlåste konflikt mellem Danmark og Indien om den danske våbensmugler Niels Holck, som Indien kræver udleveret som formodet hovedansvarlig for nedkastning af fire ton våben $o g$ ammunition til ekstremister i regionen Purulia i delstaten Vestbengalen for 17 år siden. Niels Holck tilbød at møde frem til en indisk retssag, men ikke i Indien.

Tilbuddet var overbragt Indiens regering efter godt et års hemmelige diplomatiske bestræbelser fra Holck og hans advokat Tyge Trier på at medvirke til at løse krisen mellem Indien og Danmark, der begyndte sommeren 2011, da Østre Landsret stadfæstede, at Holck ikke skal udvises på grund af 'udbredt og systematisk brug af tortur' samt 'overfyldte fængsler med mangel på mad og medicinsk behandling' i Indien.

"Det er sket ad diplomatiske og forretningsmæssige kanaler. Jeg har først tilbudt inderne at stille op til en afhøring og senest at lade en in- disk domstol gennemføre en retssag mod mig på neutral grund", sagde Holck til Politiken 25. september. Hvis Indien bare havde taget $\emptyset$ stre Landsrets afgørelse til efterretning, "var jeg nok også stoppet der. Det vigtigste for mig er at forsøge at medvirke til at få bilagt konflikten", sagde Holck, der ikke ville fortælle, hvem der har været involveret i forhandlingerne med inderne.

Holck har i skrivende stund så vidt vides ikke fået svar på sit tilbud, men Indiens regering meddelte kort efter, at den 'vil forøge presset' på Danmark og 'undersøge forskellige muligheder', herunder at føre retssagen på Indiens ambassade i København. Indien ville oprindelig retsforfølge Holck i Kolkata (tidl. Calcutta). Udenrigsminister Villy Søvndal (SF) sagde, at han er klar til at pakke kufferten og tage til Indien, hvis det kan hjælpe. "Den her konflikt er uheldig både for Danmark og Indien”, sagde Søvndal.

Det er dog kun Danmark sagen 
rammer hårdt med nedfrysning af officielle relationer og nej til visa til journalister, erhvervsfolk og hjælpearbejdere. Og Indien har afvist danske tilbud om at komme til Delhi og forklare det danske syn på sagen nærmere.

\section{Hvad gjorde Holck?}

Det hele startede tidligt om morgenen 18. december 1995, hvor beboere i den vestbengalske landsby Khatanga fandt 'gaver', som i nattens løb var dumpet ned fra himlen. Ifølge vidner lå kasser spredt på markerne, indhyllet i faldskærme. Lokale hamstrede af våbenkasserne, men politiet fandt frem til omkring fire ton Kalasjnikov-geværer, raketstyr, granater, anti-tank raketter og tusindvis af patroner.

Våbnene var tiltænkt den indiske sekt Ananda Marga, der er eftersøgt i flere lande for smugleri og for mord på afhoppere. Holck er tidligere munk i kulten. Ud over dæknavnet Kim Peter Davy er han også kendt som 'barfodsrøveren' efter at være flygtet fra politiet på bare fødder. Politiet jagtede ham for deltagelse i to pengetransportrøverier i Nivå, hvor udbyttet blandt andet skulle bruges til hjælpearbejde i Indien.

Holck er fra Års og voksede op i Nordsjælland. I 1981 begyndte han at arbejde for fattige og forfulgte, blandt andet i Calcuttas (siden Kolkata) slum. Han organiserede guld- smugling i Asien, men angiveligt kun for at finansiere udviklingsprojekter via blandt andre Ananda Marga, der var stærkt til stede i Danmark i 1980'erne, hvor den var overvåget af $\mathrm{PET}$ på anmodning fra den indiske regering.

Hvad Ananda Marga er for en organisation, er der flere meninger om. Ifølge involverede i projekter som økologiske bagerier i Danmark er der tale om en social og åndelig bevægelse, der underviser i yoga, meditation og personlig udvikling, og som på våbennedkastningens tid var udsat for ulovlige overgreb fra Vestbengalens kommunistiske regering. Ifølge andre er Ananda Marga en højreorienteret fanatisk sekt, der kæmper for et totalitært verdensrige og bekæmpede en demokratisk valgt kommunistisk lokalregering med terror.

Holck sagde i et tv-interview i 2010, at nedkastningen var 'et lovligt forsvar mod årtiers mord, tortur og voldtægt', som Indiens Kommunistparti skulle være ansvarlig for $\mathrm{i}$ Vestbengalen.

Holck har fra starten indrømmet, at han deltog i nedkastningen fra et lettisk fly hin decembernat i Purulia i Vestbengalen. Seks andre medvirkende blev pågrebet og idømt livstidsdomme i Indien, mens Holck var den eneste, som det lykkedes at flygte, da deres fly blevet tvunget til landing i Mumbai.

En tid var han under jorden, og politiet hævdede ved flere lejlighe- 
der, at de ikke kunne finde ham, selv om det som regel var let for journalister.

De dømte for våbensmugleriet ad luftvejen var briten Peter Bleach og fem letter, der fik russisk statsborgerskab, mens de var i indisk fangenskab. Efter pres fra Rusland og Storbritannien blev de seks benådet, de fire 'nyrussere' i 2000 og Bleach i 2004 efter otte år i et fængsel i Kolkota. Bleach sagde efter hjemkomsten til Storbritannien: "I indernes øje var jeg en lille fisk. De ser Niels Holck som ringleder for nedkastningen".

\section{Hvorfor Indien insisterer}

For Indien er der primært tale om krænket stolthed i sagen om Niels Holck, der i Indien er kendt som Kim Davy. Det har vakt forståelig harme i Indien, at Davy hidtil er gået fri for at blive draget til ansvar for deltagelse $\mathrm{i}$ våbenleverancer til en organisation, der har været inddraget i terror. Indien er et af de lande i verden, der historisk har været mest udsat for terror og er forblevet et af de mest terrortruede. Den forståelige følsomhed over for terrorhandlinger blev kraftigt øget af terrorangrebene i Mumbai i 2008.

Det var et vink med en vognstang til hele Europa, da Indien reagerede med blandt andet nej til visa til danske forretningsfolk og journalister på det, som Indien opfatter som dansk arrogance i konflikten om
Niels Holck. Sådan behandler man ikke den opstigende stormagt, var det klare budskab.

Indien føler sig især krænket, fordi landet klart bakkede op bag USA's og vestlige allieredes kamp imod terror efter terrorangrebet på USA 11. september 2001.

Den indiske journalist Devapio Das, der er bosat i København, sagde til Copenhagen Post i september, at mange indere forstår bekymringen hos danske domstole for forholdene $\mathrm{i}$ indiske fængsler. "Men indere er ophidsede over al hykleriet om sagen. Indien er et demokratisk land, der har samarbejdet med andre lande imod terrorisme. Så det er nedtrykkende, at Danmark ikke kan samarbejde med Indien i denne sag. Mange af os accepterer, at domstolen har truffet en beslutning, så sådan er det. Men under det ligger dobbeltmoral og hykleri. Vi er et land, der er stolt over vores demokrati, og som burde kunne samarbejde med Danmark om en helt oplagt kriminel handling", skrev Devapio Das.

Ifølge Holck skete våbennedkastningen som led i en sammensværgelse, som den indiske regering og den britiske efterretningstjeneste MI5 deltog i for at vælte den kommunistiske regering i Vestbengalen. Holck skal have fået garanti for sin sikkerhed af de indiske myndigheder, som han blandt andet fortæller i selvbiografien De kalder mig terrorist (2008).

Flere indiske medier har tilkende- 
givet, at der meget vel kan være noget om, at indiske myndigheder $\mathrm{i}$ hvert fald indirekte havde godkendt våbennedkastningen, da Delhi var interesseret $i$ at destabilisere den kommunistiske regering i Vestbengalen. Nedkastningen skete på en brutal baggrund med en regering $i$ Vestbengalen, der afgjort ikke var blandt guds bedste børn.

Blandt vestlige efterretningstjenester herskede frygt for, at pendulet skulle svinge til fordel for kommunisterne i Indien. Den angst eksisterede især i den gamle kolonimagt, Storbritannien, så derfor formodninger om MI5's medvirken.

At dansk efterretningstjeneste kan være informeret underbygges af, at den aldrig har afhørt Niels Holck.

Det anerkendte nyhedsmagasin, Tehelka skrev, at nok er Kim Davy 'den hovedanklagede for Purulia våbennedkastningen', men regeringen i Delhi har alligevel god grund "til at gå på listesko, da den ikke ønsker, at offentligheden skal blive bekendt med, hvordan Davy faktisk undslap, efter at han var blevet pågrebet af indiske sikkerhedsstyrker i Mumbai Lufthavn”. Alle anklagede blev pågrebet ved den lejlighed, og kun Holck slap fri.

Han fik efter eget udsagn hjælp til at komme til Nepal af et indiske parlamentsmedlem, der stod regeringslederen nær. Fra Nepal tog Holck et fly til Tyskland og har siden opholdt sig i Danmark.

Det hører med til forståelse af In- diens reaktioner, at indisk Højesteret spiller en langt større rolle end dansk Højesteret. I Indien indbringes alle slags sager konstant for Højesteret. Der er således ikke tale om manglende indisk forståelse for det danske retssystem, når Indien har lagt så stor vægt på at få Højesteret indbragt. Der er derimod tale om, at inderne har søgt bistand hos ikke mindre en tre advokatfirmaer, der har peget på en hidtil ubrugt mulighed i dansk lovgivning, at ikke bare statsadvokaten, men også en minister kan indbringe en sag for Højesteret. Den mulighed havde Lene Espersen som justitsminister, men gjorde ikke brug af den.

Den indiske journalist Praveen Swami skrev i Information: "Selv om dette forsvar for menneskerettigheder (begrundelsen for ikke at udlevere Holck. red.) kan være rigtigt, er det ikke hele sandheden. Danmarks indsats i Vestens krig mod islamisk terrorisme antyder, at de samme principper ikke gælder, når terroristerne ikke er hvide, og ofrene ikke er brune".

Et eksempel er kort før våbennedkastningen over Vestbengalen.

I juni 1995 underskrev USA's daværende præsident, Bill Clinton, det direktiv, der gav USA juridisk myndighed til at kidnappe formodede terrorister i udlandet. Danmark var indblandet i den allerførste CIAoperation efter dekretet: I september 1995 blev den egyptiske jihadist Talat Fuad Qasim kidnappet i Kroa- 
tien, afleveret til sit hjemland og sandsynligvis henrettet. Qasim blev beskyldt for medvirken til mordet på Egyptens præsident Anwar Sadat og dømt for terrorisme ved en egyptisk domstol i 1992, men han fik asyl i Danmark. PET menes underrettet om kidnapningen af Qasim.

Diplomatiske telegrammer, som WikiLeaks har offentliggjort, stiller også dansk politik i et mindre gunstigt lys. En embedsmand i Udenrigsministeriet fortalte USA, at regeringens protest blot var formel. I en indberetning fra februar 2008 roste James Cain, den daværende amerikanske ambassadør i København, Danmarks regering for "at have undgået en uafhængig undersøgelse”.

Praveen Swami skrev om kritikken af Indiens retssystem og fængselsvilkår i Information 26. juli 2012: "Det er ikke den egentlige kerne i denne sag. Den europæiske debat om inhuman behandling af fanger dækker over betydeligt hykleri. Der en klar og synlig forskel mellem Danmarks erklærede værdier og landets mindre dydige adfærd ved udleveringer. Årsagen er ikke svær at finde: Danmark står over for trusler fra jihadister, ikke fra bengalske hindukulter. Som den danske mellemøstforsker Michael Irving Jensen skrev i 2006: 'På trods af deres begrænsede antal har jihadisterne formået at kile sig ind mellem den muslimske befolkning og det danske samfund. Brune menneskers retssystem er ikke for hvide mennesker. Høje principper kan tilsyneladende sagtens hvile på et alt andet end opbyggeligt grundlag'".

Praveen Swami beskyldte således Danmark for racisme.

\section{Dansk ja og nej}

Den danske regering viste samarbejdsvilje, da Justitsministeriet under Lene Espersen 12. april 2010 tilkendegav, at regeringen ville udlevere Holck til Indien. Det skete, efter at Indien havde lovet, at han ikke ville blive dødsdømt, at han ville blive behandlet humant, tilladt kontakt med familien og Danmarks ambassade i New Delhi samt blive overført til Danmark til afsoning af en forventet straf senest tre uger efter domsafsigelse. Holck blev anholdt i april 2010 og fremstillet i grundlovsforhør. Ved arrestationen var han i besiddelse af to falske britiske pas. Da Holck igen blev sat på fri fod, fik han inddraget sit pas og skulle melde sig til politiet to gange om ugen.

Holck blev den anden dansker, der kunne udleveres til retsforfølgelse til et land uden for EU, efter at den danske kvinde Camilla Broe tidligere var udleveret til USA. Den udleveringsmulighed blev der skabt grundlag for med en lovændring til skærpelse af indsatsen mod terrorisme som følge af terrorangrebet på USA 11. september 2001.

Men så lagde byretten i Hillerød, hvor Holck boede, og siden Østre Landsret sig imellem og gav Holcks 
advokat medhold i, at han ikke kunne udleveres på grund af fare for tortur i indisk fangenskab. Rigsadvokaten, Jørgen Steen Sørensen, opgav at indbringe sagen for Højesteret på trods af gentagne anmodninger fra Indien om netop det.

Med baggrund i Holck-sagen aflyste Indiens præsident, Pratibha Devisingh Patil, i februar 2012 et besøg i Danmark, der var planlagt til få måneder senere.

I løbet af 2012 blev konflikten stadig værre. Indiske topembedsmænd blev instrueret om ikke at mødes med repræsentanter for danske myndigheder, og i juli skrev den indiske avis The Telegraph, at Indien afviste visumansøgninger fra Danmark. Det danske Udenrigsministerium afviste dog at have modtaget formel information om visumafvisninger, men Mellemfolkeligt Samvirke kunne meddele, at fem af deres frivillige havde fået nej til visum i slutningen af 2011 og begyndelse af 2012. Flere danske journalister fik samme behandling, også når det drejede sig om ren turisme i Indien. Indiens vrede over Danmarks behandling af landets udleveringsanmodning i sagen om den terroranklagede Holck 'får nu håndgribelige konsekvenser', skrev The Telegraph, der mente, at de nye retningslinjer allerede var sat i værk hos de indiske ambassader i København, Oslo og Stockholm, men uden officiel annoncering. Visumstramningerne skulle ses som en besked til alle EU- lande om ikke at behandle Indien 'urimeligt', sagde en højt placeret regeringskilde til avisen. Han medgav, at det kunne ramme Indiens forhold til EU. "Men de har mere brug for os, end vi har for dem. Deres investeringer i Indien skaber tusinder af job i deres lande," sagde regeringskilden.

Ifølge The Telegraph gælder det alle officielle besøgende, forretningsmænd og ansatte hos NGO'er, men ambassaderne havde også fået besked på at udskyde ansøgninger om turistvisum. - 'Næsten alle, der ønsker at besøge Indien,' var avisens formulering. Og det kan også få konsekvenser for skandinaviske NGO'er, der arbejder i Indien. Ifølge The Telegraph ville skandinaver ved organisationer, der arbejder i det uroprægede Nordøst blandt oprindelige folk, eller i den omstridte Kashmir Provins komme under scanneren og "nogle vil blive bedt om at forlade landet, hvis deres aktiviteter anses som i strid med indiske interesser".

En ny sag har understøttet torturanklagerne imod Indien. 27. september 2012 krævede Human Rights Watch (HRW) en efterforskning af anklager imod politiet i delstaten Punjab for at have tortureret sikh-lederen Kulvir Singh Barapind efter dennes arrestation 20. september, anklaget for at føre krig imod staten, besidde eksplosivt materiale og for bortførelse. Hans forsvarer sagde til HRW, at politiet havde gi- 
vet ham elektrochok i ørerne samt slået og ydmyget ham.

"Indiske myndigheder har sjældent benægtet, at tortur er et problem, men deres mangel på at garantere sikkerhed for en involveret $\mathrm{i}$ en højprofileret international sag viser, hvor udbredt det er", sagde Meenakshi Ganguly, Sydasien direktør for HRW. Menneskeretsorganisationen understreger, at udenlandske regeringer må tage hensyn til det, når de overvejer at udlevere nogen til Indien. Det er de også forpligtet til ifølge Konventionen imod Tortur, som Indien ikke har ratificeret.

Indisk politi har indrømmet, at uden ordentlig uddannelse og udstyr til at samle beviser og under pres for at opklare forbrydelser bruger overbelastede politistyrker ofte tortur som det mest effektive våben til at aftvinge tilståelser.

HRW har grundigt dokumenteret både hærens og politiets brug af tortur. Barapindis sag har ingen direkte relevans for Holcks, men den skærper international bevidsthed om problemerne med tortur i landet. Det er således også en højprofileret påminder til Indiens regering om at gøre noget ved landets kroniske problem med tortur i fængsler.

I Niels Holcks sag er der tale om, at han har tilstået, så den grund til at anvende tortur er bortfaldet. Faren for Holck er betragteligt mindsket, når danske myndigheder vil have ret til at føre tilsyn med forholdene, som Holck eventuelt skulle i varetægtsfængsel under. Under alle omstændigheder ser Indien det som en grov krænkelse at afvise, at landet kan give troværdige garantier, så det er givet en sag, som kan belaste det dansk-indiske forhold længe endnu.

Vibeke Sperling er udenrigskorrespondent ved dagbladet Politiken og redaktør af Udenrigs. 